\title{
Effects of Dynamic Exercise and Dynamic Resistance Training in Rehabilitation of Patients after Surgical Coronary Revascularization
}

\author{
Slavica Kozomara, Ivana Krstić \\ Institute for Treatment and Rehabilitation "Niška Banja", Niška Banja Serbia
}

SUMMARY

Cardiac rehabilitation is an integral part of the complex therapy of cardiac patients.

The aim of this study was to determine the effect of dynamic exercise and dynamic resistance training on exertion tolerance, muscle strength of the upper and lower extremities, and respiratory index in patients after surgical coronary revascularization.

The study included 84 patients divided into two groups. Both groups of respondents were included in the complex cardiac rehabilitation program of the interval type. In the first group, the patients performed dynamic exercise. The second group of patients received a combination of dynamic exercise and dynamic resistance training.

At the end of the rehabilitation treatment, which lasted 21 days, a statistically significant difference in muscle strength of the upper and lower limbs was observed in both groups $(\mathrm{p}<0.05)$; statistically significant difference was found in relation to exertion tolerance in both groups $(\mathrm{p}<0.001)$; a statistically significant difference in duration of exercise stress test was observed in the both groups $(p<0.05)$; respiratory index values showed statistically significant differences in both groups $(\mathrm{p}<0.001)$.

After the rehabilitation treatment, in both groups of patients there were statistically significant differences in increasing the muscle strength of the upper and lower extremities, exertion tolerance, and respiratory index; however, beneficial effects of physical training were more pronounced in the group of subjects included in the program of resistance exercise for the upper and lower extremities.

Key words: physical training, muscular strength, exertion tolerance, respiratory index 


\section{INTRODUCTION}

Cardiac rehabilitation is an integral part of the complex therapy of cardiac patients. Nowadays, cardiac rehabilitation (CR) is characterized by extensive and long-term activities, including clinical evaluation, physical training, modification of risk factors, drug therapy, education for healthy living, psychological assistance, counseling related to the patient's occupation and balneotherapy (1). Rehabilitation begins with the first contact with a patient and is a life-long process (2).

Physical training is defined as systematic physical activity performed at the level higher than that of usual activities. Aerobic exercise includes different exercises and physical activities that stimulate the activities of the heart and lungs long enough to produce positive outcomes. It is characterized by involving the large muscle groups of leg muscles, torso, arms, and shoulder girdle during dynamic exercise in which stress and relaxation rhythmically alternate (3).

Exercise programs have long consisted of dynamic lower-extremity exercise. A large body of evidence has demonstrated that resistance training, if adequately prescribed and supervised, exerts the positive effects on muscle strength and endurance, correction of coronary risk factors, cardiovascular function, metabolism, and psychophysical well-being. Contraindications to resistance training are similar to those in aerobic training of cardiac patients. Although resistance training has been accepted as a means for developing and maintaining of muscular strength, endurance and muscle mass $(4,5)$, its beneficial impact on the risk factors and chronic diseases has been recognized only recently (6-8). Up to 1990, resistance training was not considered an integral part of the recommended guidelines for the rehabilitation of cardiovascular patients neither by the American Heart Association nor the American College of Sports Medicine (ACSM). In 1990, ACSM was the first to recognize resistance training as an important component of the comprehensive training (9). The initial resistance or weight should be set at a moderate level which allows the patient to achieve an appropriate number of repetitions at a safe and high level, 13 to 15 on the Borg scale of perceived exertion (10). What is important in this early stage of the training is to provide time for musculoskeletal adaptations, thus reducing the possibility of muscle overexertion and injuries $(11,12)$. Each repetition of exercise should include a slow, controlled movement ( $\approx 2$ seconds up and four seconds down) i.e. the entire respiratory cycle (inspiration-expiration).The level of resistance is determined based on the maximum weight that could be used to perform one repetition. It is recommended that $30 \%$ to $40 \%$ of the repetition maximum for the upper extremities and $50 \%$ to $60 \%$ of the repetition maximum for the lower extremities can be used as the starting weight for the first resistance training. When the patient can safely and easily lift a given weight for up to 12 to 15 repetitions, resistance can be increased by $5 \%$. If the patient is unable to complete the minimum number of repetitions (8 or 10), weight should be reduced. For every patient, an appropriate number of repetitions that will lead to the acceptable level of exertion within 3 to 4 weeks should be determined. As the level of fatigue is an important factor for achieving optimal benefits of training and is not connected with an increased risk of cardiovascular events in low-risk cardiac patients $(13,14)$, resistance training up to the levels of fatigue is recommended (11, 12).

Low-level resistance training (e.g. the use of rubber band devices, small hand weights, and wall pulleys) should be started 2 to 3 weeks after a heart attack. Surgical patients should avoid resistance training within three months after surgical coronary revascularization and sternotomy. Moreover, the stability of the sternum should be checked before inclusion in the resistance training program.

The aim of this study was to determine the effect of dynamic exercise and dynamic resistance exercise on exertion tolerance, muscular strength of the upper and lower extremities, and respiratory index in patients after surgical coronary revascularization.

\section{PATIENTS AND METHODS}

The research was conducted at the Institute for Treatment and Rehabilitation "Niška Banja" as a prospective clinical study in the period from May 2015 to August 2016. It included patients who underwent surgical coronary revascularization and were afterwards included in the program of cardiac rehabilitation in duration of 21 days. In all patients, the postoperative period lasted 3-4 months, i.e. $3 \pm 0.25$ months on average. Postoperatively, ejection fraction was echocardiographically estimated to be over $40 \%$. The study included 84 patients, divided into two groups, aged between 56 and 73 years. Both groups of respondents were included in the complex cardiovascular rehabilitation program consisting of bicycle ergometer exercise, walking and kinetic physical therapy. Before starting the physiccal training, the patients underwent a progressive uninterrupted exercise stress test with the initial power 
output of $25 \mathrm{~W}$ and successive increase in the output by $25 \mathrm{~W}$ per 3 minutes to achieve the submaximal heart rate. The test was previously interrupted due to anginal discomfort, increase in blood pressure above $240 / 120 \mathrm{mmHg}$, heart rhythm disorders, pronounced fatigue, and claudication. The patients in whom malignant heart rhythm disorders and ischemic changes on ECG were registered in the course of the exercise stress test were not included in the study. A daily physical training was controlled and individually tailored to each patient.

The physical training, which started with 5-10 minutes "warm-up", was continued with a 30-minute workout (of interval type) and finished with 5-10 minute "cooling down". The first group of patients performed dynamic exercises for the lower limbs, trunk, upper extremities, and shoulder girdle. In the second group of patients, a combination of dynamic exercise and dynamic resistance training (for the upper and lower extremities) was applied, using free weights of $1 \mathrm{~kg}$ and $2 \mathrm{~kg}$ for hands and feet, respectively. Dynamic resistance training was applied two times a week.

Both groups of patients were assigned incline walking (with inclination of varying degrees) on tracks 1690 meters in length, walking speed 70-90 steps per minutes, and step length of 0.75 meters. Duration of training was 25-30minutes.

Interval walking (green walking track) included a 3-minute walk, with 70-90 steps per minutes, followed by one-minute walk with 90-120 steps per minutes. Stride length was $0.75 \mathrm{~m}$, track length $1600 \mathrm{~m}$. The duration of training was 25-30 min.

Interval training on bicycle ergometer was individually tailored. The level of resistance was 70\% of the level achieved during the exercise stress test. The speed was 50-70 rpm, duration of training 12-15 minutes.

The patients in the examined groups had the following parameters analyzed:

- muscular strength of the upper and lower extremities (expressed in kilograms) was determined in both groups of examinees at the beginning and end of the rehabilitation treatment using dynamometer Pelican 1150 case;

- exertion tolerance determined with the exercise stress test at the beginning and end of the rehabilitation treatment, expressed in watts (W);

- duration of exercise stress test expressed in seconds;
- anthropometric measurements: mobility of the thorax was estimated using the respiratory index, a measuring tape (at the height of the breast nipple), and based on inspiratory-expiratory differences);

-statistical analysis was performed using the statistical software package SPSS IBM. For the determination of the statistical significance, the following statistical tests were used: Student's t-test, Friedman and Cochran test.

\section{RESULTS}

The study included 84 patients, divided into two groups, aged between 56 and 73 years. The first group consisted of 38 patients, whereas the second group included 46 patients. In the first group, there were 22 male and 16 female patients, mean age $66 \pm$ 3.4 years. In the second group, there were 26 male and 20 female patients, mean age $63 \pm 6.2$ years.

At the beginning of the rehabilitation treatment, no statistically significant differences in muscular strength and exertion tolerance were found ( $p>0.05)$. At the end of the rehabilitation treatment, a statistically significant difference in muscular strength of the upper and lower limbs was observed in both groups, with highly statistically significant difference found in the second group of patients $(p<0.001)$; statistically significant difference was also observed among the groups $(\mathrm{p}<0.05)$ (Table 1 and 2$)$.

Table 1: Muscular strength of the upper extremities in the examined groups before and after the physical training

\begin{tabular}{c|c|c|c}
\hline \hline & MS 1(kg) & MS2(kg) & $\mathrm{p}$ \\
\hline $\begin{array}{c}\text { I group } \\
(\mathrm{n}=38)\end{array}$ & $2.94 \pm 0.65$ & $3.78 \pm 0.57$ & $<0.05$ \\
\hline $\begin{array}{c}\text { II group } \\
(\mathrm{n}=46)\end{array}$ & $2.91 \pm 0.60$ & $4.32 \pm 0.45$ & $<0.001$ \\
\hline $\mathrm{P}$ & $>0.05$ & $<0.05$ & \\
\hline \hline
\end{tabular}

MS1 (kg) - muscle strength of the upper extremities before starting the physical training, expressed in $\mathrm{kg}$

MS2 (kg) - muscular strength of the upper extremities after physical training, expressed in $\mathrm{kg}$ 
Table 2: Muscular strength of the lower extremities in the examined groups before and after the physical training

\begin{tabular}{c|c|c|c}
\hline \hline & MS 1(kg) & MS2(kg) & $\mathrm{p}$ \\
\hline $\begin{array}{c}\text { I group } \\
(\mathrm{n}=38)\end{array}$ & $3.34 \pm 0.65$ & $4.12 \pm 0.57$ & $<0.05$ \\
\hline $\begin{array}{c}\text { II group } \\
(\mathrm{n}=46)\end{array}$ & $3.10 \pm 0.60$ & $4.85 \pm 0.45$ & $<0.001$ \\
\hline $\mathrm{P}$ & $>0.05$ & $<0.05$ & \\
\hline \hline
\end{tabular}

MS1 (kg) - muscular strength of the upper extremities before starting the physical training, expressed in $\mathrm{kg}$

MS2 (kg) - muscular strength of the lower extremities after physical training, expressed in $\mathrm{kg}$

At the end of the rehabilitation treatment, a statistically significant difference in exertion tolerance was observed in both groups as well as between the groups $(\mathrm{p}<0.001)$ (Table 3).There was a statistically significant difference in duration of the exercise stress test at the end of the rehabilitation in the first group of patients $(\mathrm{p}<0.05)$, whereas this difference was highly significant in the second group of patients $(p<0.001)$ (Table 4).

The values of respiratory index were statistically significantly higher in both groups after the rehabilitation treatment, whereby a more favorable effect was achieved in the group of patients who practiced resistance exercise (group II) $(p<0.001)$ (Table 5).

\section{DISCUSSION}

According to the World Health Organization, cardiac rehabilitation is a set of activities and interventions needed for achieving the best physical, mental and social condition, so that patients with chronic or post-acute cardiovascular disease can reclaim their place in society and lead an active life. Today, the rehabilitation of cardiac patients is recommended by the European and American Heart Association for the treatment of cardiovascular disease (15-19).

Table 3. Exertion tolerance in the examined groups before and after the physical training

\begin{tabular}{|c|c|c|c|c|}
\hline & W1 & W2 & $\%$ & $\mathrm{p}$ \\
\hline $\begin{array}{l}\text { I group } \\
(\mathrm{n}=38)\end{array}$ & $\begin{array}{c}52.35 \pm \\
7.50\end{array}$ & $87.00 \pm 5.0$ & 66.19 & $<0.001$ \\
\hline $\begin{array}{l}\text { II group } \\
(\mathrm{n}=46)\end{array}$ & $\begin{array}{c}54.15 \pm \\
8.25\end{array}$ & $95.05 \pm 2.5$ & 75.53 & $<0.001$ \\
\hline $\mathrm{p}$ & $>0.05$ & $<0.05$ & & \\
\hline
\end{tabular}

W1- Exertion tolerance during exercise stress test before stating the physical training, expressed in (W) W2- Exertion tolerance during exercise stress test after the physical training, expressed in (W)

Table 4. Duration of the exercise stress test in the examined groups before and after the physical training

\begin{tabular}{c|c|c|c}
\hline \hline & $\begin{array}{c}\text { Duration of test } \\
1(\mathrm{sec})\end{array}$ & $\begin{array}{c}\text { Duration of test } \\
2(\mathrm{sec})\end{array}$ & $\mathrm{p}$ \\
\hline $\begin{array}{c}\text { I group } \\
(\mathrm{n}=38)\end{array}$ & $434.36 \pm 115.45$ & $589.86 \pm 108.46$ & $<0.05$ \\
\hline $\begin{array}{c}\text { II group } \\
(\mathrm{n}=46)\end{array}$ & $456.48 \pm 76.24$ & $696.80 \pm 154.38$ & $<0.001$ \\
\hline $\mathrm{p}$ & $>0.05$ & $<0.05$ & \\
\hline \hline
\end{tabular}


Table 5. The values of respiratory index in the examined groups before and after the physical training

\begin{tabular}{c|c|c|c|c}
\hline \hline & $\mathrm{cm}(1)$ & $\mathrm{cm}(2)$ & $\%$ & $\mathrm{p}$ \\
\hline $\begin{array}{c}\text { I group } \\
(\mathrm{n}=38)\end{array}$ & $3.35 \pm 1.34$ & $5.50 \pm 1.05$ & 64.18 & $<0.001$ \\
\hline $\begin{array}{c}\text { II group } \\
(\mathrm{n}=46)\end{array}$ & $3.21 \pm 0.25$ & $6.05 \pm 1.50$ & 88.47 & $<0.001$ \\
\hline $\mathrm{p}$ & $>0.05$ & $<0.05$ & & \\
\hline \hline
\end{tabular}

Many cardiac patients do not have physical strength and confidence to perform everyday activities. Training patients to perform dynamic resistance exercise is an effective method for the improvement of muscular strength and endurance, control of various chronic conditions, modification of coronary risk factors, and finally for increasing the psychosocial benefits.

Cardiac patients require physical training with minimal efforts related to the daily activities. Unfortunately, many patients do not have the physical strength or confidence to perform these tasks. By analyzing the obtained results, we concluded that both programs of exercises, dynamic exercise with and without resistance, have a favorable effect on increasing the muscular strength, length of the next exercise stress test, tolerance of a higher level of resistance, and higher values of respiratory index.

A considerably more favorable effect was achieved by applying dynamic resistance exercise with respect to the increase in muscle strength ( $p<0.05)$, tolerance of physical exertion $(\mathrm{p}<0.001)$ and endurance $(p<0.05)$. The values of respiratory index in both groups were statistically significantly higher after the rehabilitation treatment $(p<0.001)$. Dynamic moderate load resistance training, as the one included in our exercise program, has been considered as a safe and effective mode of exercise in CR (20-23). A large number of studies have demonstrated that aerobic training improves exercise tolerance and muscle strength in patients undergoing open-heart surgery and patients with myocardial infarction (24-26).

Barros et al. tried to clarify the loss of ventilatory capacity in the postoperative period in patients undergoing surgical coronary revascularization and to test the assumption that respiratory muscle training (RMT), when performed after surgery, can improve the ventilation in this group of patients. The estimation was done using the following variables (preoperatively, on the first postoperative day and the day of discharge): pain, dyspnea (Borg), maximal inspiratory and expiratory pressures (MIP and MEP), peak of expiratory flow (PEF), tidal volume (VT) and hospital days. The conclusion indicated that patients undergoing coronary artery bypass grafting experienced a loss of respiratory muscle strength. The respiratory muscle training, done in the postoperative period, was effective in restoring the following parameters in this population: MIP, MEP and PEF (27).

Recently, Gonçalves et al. found that patients demonstrated good tolerance during the practice of resistance exercise which was considered safe due to the absence of complications or cardiovascular events. These authors considered the following benefits of resistance exercise in cardiac patients: health improvement, control of risk factors as well as an increase in functional capacity. However, it is vital to stress the importance of specific and individual assessment prior to exercise prescription (28).

After surgical revascularization of the heart, resistance exercise should not be performed by patients with instability of the sternum or post-surgery incision infection. Considerable damages to the soft tissues and bones of the chest wall may occur during the operation. If rehabilitation is not carried out timely, the possible consequences are the development of adhesions, muscle weakness as well as muscle shortening. Exercises should be focused on arms, shoulder girdle, and chest. The stretching and flexibility exercises could be started as early as 24 hours after surgical revascularization of the heart.

The physical training is associated with different degrees of a short-term risk but a long-term favorable effect. The most common side effects are mild bone and muscle injuries. Physical activity should be gradually increased, which significantly reduces the risk of complications. 
The effect of physical trainings with resistance that is applied in patients after surgical revascularization of the heart has been tested. Studies on this topic are scarce, especially in connection with the beginning of the exercise in this population, and it is therefore difficult to compare them with our results, which highlights the importance of this research.

\section{CONCLUSION}

Physical training is an important method of rehabilitation and should be started immediately after the coronary event or surgical intervention. After the reha- bilitation treatment of patients for surgical coronary revascularization, for a period of 21 days, there was a statistically significant difference in increasing the muscular strength of the upper and lower extremities, tolerance of physical exertion, and respiratory index. More favorable effects on the studied parameters were observed in the group that practiced dynamic resistance exercise compared to the use of dynamic exercise only. Our results point to the advantage of combining dynamic resistance training with dynamic exercise in the rehabilitation of patients after surgical coronary revascularization. 


\section{References}

1. Deljanin Ilic M. Rehabilitation of cardiovascular patients. In Ilic $S$, Internal Medicine, Prosveta, Nis, 2004; 272-8.

2. Athur SL, Barry A, Franclin PD, et al. Cardiac rehabilitation and secondary prevention of coronary heart disise. Circulation 2005; 111: 369-76

3. Southern WM, Ryan TE, Kepple K, et al. Reduced skeletal muscle oxidative capacity and impaired training adaptations in heart failure. Physiol Rep $2015 ; 3$.

https://doi.org/10.14814/phy2.12353

4. Atha J. Strengthening muscle. Exerc Sport Sci Rev 1981; 9: 1-73.

https://doi.org/10.1249/00003677-198101000-00001

5. Komi PV. ed.Strength and Power in Sport. Oxford, UK: Blackwell Scientific Publications; 1991.

6. Pollock ML, Vincent KR. Resistance training for health. The President's Council on Physical Fitness and Sports Research Digest 1996; Series 2, No. 8.

7. Pollock ML, Evans WJ. Resistance training for health and disease. Med Sci Sports Exerc 1999; 31: $10-1$.

https://doi.org/10.1097/00005768-199901000-00003

8. US Department of Health and Human Services. Physical Activity and Health: A Report of the Surgeon General. Atlanta, Ga: US Dept of Health and Human Services, Centers for Disease Control and Prevention, National Center for Chronic Disease Prevention and Health Promotion; 1996.

9. American College of Sports Medicine position stand: the recommended quantity and quality of exercise for developing and maintaining cardiorespiratory and muscular fitness in healthy adults. Med Sci Sports Exerc 1990; 22: 265-74.
10. Borg GAV. Psychophysical bases of perceived exertion. Med Sci Sports Exerc 1982; 14: 377-81. https://doi.org/10.1249/00005768-198205000-00012

11. American College of Sports Medicine position stand: the recommended quantity and quality of exercise for developing and maintaining cardiorespiratory and muscular fitness and flexibility in healthy adults. Med Sci Sports Exerc 1998; 30: 975-91

12. Fleck SJ, Kraemer WJ. Designing Resistance Training Programs. 2nd ed. Champaign, Ill: Human Kinetics; 1997.

13. Gordon NF, Kohl HW III, Pollock ML, et al. Cardiovascular safety of maximal strength testing in healthy adults. Am J Cardiol 1995; 76: 851-3. https://doi.org/10.1016/S0002-9149(99)80245-8

14. Wenger NK, Froelicher ES, Smith LK, et al. Cardiac Rehabilitation as Secondary Prevention. Clinical Practice Guideline No. 17. Rockville, Md: US Dept of Health and Human Services, Public Health Service, Agency for Health Care Policy and Research and the National Heart, Lung, and Blood Institute; 1995. AHCPR publication No. 960672.

15. Taylor RS, Brown A, Ebrahim S, et al. Exercise based rehabilitation for patients with coronary heart disease: systematic review and meta-analysis of randomized controlled trials. Am J Med 2004; 116: 682-92.

https://doi.org/10.1016/j.amjmed.2004.01.009

16. Balady GJ, Williams MA, Ades PA, et al. Core components of cardiac rehabilitation/secondary prevention programs: 2007 update: a scientific statement from the American Heart Association Exercise, Cardiac Rehabilitation, and Prevention Committee, the Council on Clinical Cardiology; the Councils on Cardiovascular Nursing, Epidemiology and Prevention, and Nutrition, Physical Activity, and Metabolism; and the American 
Association of Cardiovascular and Pulmonary Rehabilitation. Circulation 2007; 115: 2675-82. https://doi.org/10.1161/CIRCULATIONAHA.106. $\underline{180945}$

17. Piepoli MF, Corra U, Benzer W, et al. Secondary prevention trough cardiac rehabilitation. 2008 Update. From knowledge to implementation. A Position Paper from the Cardiac Rehabilitation Section of the European Association of Cardiac Rehabilitation and Prevention. Eur J Cardiovasc Prev Rehabil 2010; 17: 1-17. https://doi.org/10.1097/H]R.0b013e3283313592

18. Thomas RJ, King $M$, Lui $K$, et al. AACVPR/ACC/AHA 2007 Performance Measures on Cardiac Rehabilitation for Referral to and Delivery of Cardiac Rehabilitation/Secondary Prevention Services. JACC 2007; 50: 1400-33. https://doi.org/10.1016/j.jacc.2007.04.033

19. Wenger NK. Current status of cardiac rehabilitation. JACC 2008; 51: 1619-31. https://doi.org/10.1016/j.jacc.2008.01.030

20. Hare DL, Ryan TM, Selig SE, et al. Resistance exercise training increases muscle strength, endurance and blood flow in patients with chronic heart failure. Am J Cardiol, 1999; 83: 1674-77. https://doi.org/10.1016/S0002-9149(99)00179-4

21. Pollock M, Franklin BA, Balady GJ, et al. Resistance exercise in individual with and without cardiovascular disease: benefits, rationale, safety, and prescription: an advisory from the committee on exercise, rehabilitation, and prevention. Council on Clinical Cardiology, American Heart Association; Circulation 2000; 101: 828-33. https://doi.org/10.1161/01.CIR.101.7.828

22. Delagardell C, Feiereisen $\mathrm{P}$, Autier $\mathrm{P}$, et al. Strength/endurance training versus endurance training in congestive heart failure. Med Sci Sport Exerc 2002; 34: 1868-87. https://doi.org/10.1097/00005768-200212000-00002

23. Selig SE, Carey MF, Menzies DG, et al. Moderateintensity resistance exercise training in patients with chronic heart failure improves strength, endurance, heart-rate variability and forearm blood flow. J Card Fail 2004; 10: 21-30. https://doi.org/10.1016/S1071-9164(03)00583-9

24. Froelicher V, Jensen D, Sullivan M, et al. A randomized trial of the effects of exercise training after coronary artery bypass surgery. Arch Intern Med 1985; 145: 689-92.

https://doi.org/10.1001/archinte.1985.00360040113 $\underline{025}$

25. Adachi $H$, Itoh $H$, Sakurai $S$, et al. Short-term physical training improves ventilatory response to exercise after coronary arterial bypass surgery. Jpn Circ J 2001; 65: 419-23

https://doi.org/10.1253/jci.65.419

26. Ueshima K, Suzuki T, Nasu M, et al. Effects of exercise training on left ventricular function evaluated by the Tei index in patients with myocardial infarction. Circ J 2005; 69: 564-6.

https://doi.org/10.1253/circi.69.564

27. Barros GF, Santos CS, Granado FB, et al. Gardenghi G. Respiratory muscle training in patients submitted to coronary arterial bypass graft. Rev Bras Cir Cardiovasc 2010; 25: 483-90. https://doi.org/10.1590/S0102-76382010000400011

28. Gonçalves ACCR, Pastre CM, Camargo JCS. Resistance exercise in heart disease: systematic review. Fisioter Mov 2012; 25: 195-205. https://doi.org/10.1590/S0103-51502012000100019 


\title{
Efekat Dinamskih vežbi sa opterećenjem na rehabilitaciju bolesnika nakon hirurške revaskularizacije srca
}

\author{
Slavica Kozomara, Ivana Krstić \\ Institut za lečenje i rehabilitaciju "Niška Banja", Niška Banja, Srbija
}

\section{SAŽETAK}

Kardiovaskularna rehbailitacija predstavlja integralni deo kompleksne terapije kardiovaskularnih bolesnika.

Cilj rada bio je da se utvrdi efekat dinamskih vežbi i vežbi sa opterećenjem na toleranciju napora, mišićnu snagu gornjih i donjih ekstremiteta i respiratorni indekskod bolesnika nakon hirurške revaskularizacije srca.

Istraživanjem su obuhvaćena 84 bolesnika podeljena u dve grupe. Obe grupe ispitanika uključene su u kompleksni program kardiovaskularne rehabilitacije intervalnog tipa.

Na kraju rehabilitacionog tretmana, koji je trajao 21 dan, statistički značajna razlika u mišićnoj snazi gornjih i donjih ekstremiteta registrovana je kod obe grupe $(\mathrm{p}<0.05)$; statistički značajna razlika registrovana je u odnosu na toleranciju napora kod obe grupe ( $p<0.001)$; statistički značajna razlika upčena je $u$ trajanju testa fizičkim opterećenjem kod obe grupe $(p<0.05)$; vrednost respiratornog indeksa pokazala je statistički značajnu razliku kod obe grupe $(p<0.001)$.

Posle rehabilitacionog tretmana, kod obe grupe ispitanika bilo je statistički značajne razlike u povećanju mišićne snage gornjih i donjih ekstremiteta, toleranciji napora i respiratornog indeksa. Povoljni efekti fizičkog treninga bili su izraženiji u grupi ispitanika uključenih u program dinamskih vežbi sa opterećenjem za gornje $i$ donje ekstremitete.

Ključne reči: fizički trening, mišićna snaga, tolerancije napora, respiratorni indeks 
Original article 